\title{
The effect of clove oil on frozen storage stability and quality of rainbow trout (Oncorhynchus mykiss)
}

\section{Gökkuşağı Alabalığı (Oncorhynchus mykiss)'nın kalitesi ve dondurulmuş depolama stabilitesi üzerine karanfil yağının etkisi}

\author{
Özlem Emir Çoban ${ }^{1 *}$ (1) • Emine Özpolat ${ }^{1}$ (b) • Nermin Karaton Kuzgun² (i) \\ ${ }_{1}^{1}$ Department of Fishing Techniques and Processing Technologies, Faculty of Fisheries, Firat University 23119 \\ ${ }^{2}$ Department of Fishing Techniques and Processing Technologies, Faculty of Fisheries, Munzur University Tunceli, Turkey \\ *Corresponding author: oecoban@firat.edu.tr
}

How to cite this paper:

Emir Çoban, Ö., Ozpolat, E. \& Karaton Kuzgun, N. (2018). The effect of clove oil on frozen storage stability and quality of rainbow trout (Oncorhynchus mykiss). Ege Journal of Fisheries and Aquatic Sciences, 35(1): 31-35. doi:10.12714/egejfas.2018.35.1.06

\begin{abstract}
Öz: Bu çalışmada, 6 ay boyunca dondurulmuş alabalık filetolarının kalitesi üzerine doğal bir koruyucu olarak karanfil yağının ( $0.5 \%$ ve $1 \%$ v/w) etkisi değerlendirildi. Vakum paketlenmiş örnekler $-18^{\circ} \mathrm{C}$ 'de depolandı. Depolama süresince mikrobiyolojik (Toplam anaerob bakteri, psikrofilik bakteri, laktik asit bakterileri ve maya-küf) ve duyusal (koku, renk, tekstür) parametreler incelendi. Mikrobiyal gelişme kontrol grubunda depolama süresince en yüksekti. Karanfil yağı vakum paket ile birlikte kullanıldığı kombinasyonlarda dondurulmuş alabalık filetolarının duyusal kalitesi üzerine olumlu etki gösterdi. Sonuçlarımıza göre karanfil yağı, etkili antibakteriyel ve doğal bir koruyucu olarak dondurulmuş gökkuşağı alabalığı kalitesini artırmak için vakum paket ile birlikte kullanılabilir.
\end{abstract}

Anahtar kelimeler: Esansiyel yağlar, karanfil yağı, dondurulmuş depolama, Gökkuşağı alabalı̆̆ı, mikrobiyolojik kalite, duyusal kalite

\begin{abstract}
The present study evaluated clove oil $(0.5 \%$ and $1 \% \mathrm{v} / \mathrm{w})$ use as a natural preservative on the quality of frozen rainbow trout fillets during of six months. Vacuum packed samples were stored at $-18{ }^{\circ} \mathrm{C}$. Microbiological parameters (total anaerobe, psychrophilic bacteria, lactic acid bacteria, mold-yeast) and sensory quality (odour, color and texture) were determined during the storage period. Microbial growth was high over a period of frozen storage for control samples. The existence of clove oil demonstrated to develop the sensory quality of frozen rainbow trout fillets when used in combination with vacuum pack. According to our results, clove oil as natural protective and influential antibacterial can be used in conjunction with vacuum pack to augment frozen stored rainbow trout quality.
\end{abstract}

Keywords: Essential oil, clove oil, rainbow trout, frozen storage, microbiological quality, sensory quality

\section{INTRODUCTION}

Frozen and chilled storage are widely used protection methods for fish and fish product, owing to the microbiological growth and some biochemical processes can be minimized with these methods. But, the quality of fish muscle will also deteriorate throughout frozen storage as the fishes have high protein and unsaturated fatty acid contents (Simeonidou et al. 1997; Tironi et al. 2010; Dusukcan et al. 2014). That's why, some measures must be taken to extend the shelf life of fish in cold storage.

Clove oil is a plant widely cultivated in the world. Its antimicrobial potential was established when its essential oil extracts killed many Gram positive and Gram negative organisms including some fungi. The antimicrobial activity of clove is attributable to eugenol, oleic acids and lipids found in its essential oils (Nzeako et al. 2006). Clove oil has been listed as a "Generally Regarded As Safe" substance by the United States Food and Drug Administration when administered at levels not exceeding $1500 \mathrm{ppm}$ in all food categories. Nontraditional preservation techniques are being developed to satisfy consumer demand with regard to nutritional and sensory aspects of foods. This increasing demand has opened new dimensions for the use of natural preservatives derived from plants and animals. In biopreservation, storage life is extended, and/or safety of food products is enhanced by using natural compounds (Nzeako et al. 2006; Yıldız Oguzhan, 2015). Besides, plant and spices extracts possessing an antioxidant activity preserve the cells from the harm caused by the free radicals and they have an major role in the antioxidant defense (Tuna Keleştemur, 2011; Tuna Keleştemur and Özdemir, 2013).

The impact of essential oils on the shelf-life of fish and fish products has been studied (Harpaz et al.,2003; Mahmoud et al., 2006; Goulas and Kontominas, 2007), but there are very limited study (Solanki et al., 2016) on fish, treated with clove oil. 
Therefore, the objective of the present study was to determine the effect of vacuum pack and in combination with the addition of clove oil, as a natural preservative, on the shelflife extension of rainbow trout (Oncorhynchus mykiss) fillets by evaluating microbiological and sensory quality.

\section{MATERIALS AND METHODS}

\section{Preparation of fish samples and storage conditions}

Clove oil was acquired from Kalsec® (Kalsec®, Inc, Kalamazoo). Fresh rainbow trout (0. mykiss) samples (varying from 250 to $280 \mathrm{~g}$ weight and total rainbow trout 150) were obtained Keban Alabalık Co. aquaculture farm located in Keban Dam Lake. Fish samples were placed in ice box and transferred within $1 \mathrm{~h}$ to the fish-processing laboratory of the Faculty of Fisheries of Firat University. Fishes were immediately weighed, gutted, headed and filleted. Then fillets were washed with water and were divided to three lots.

First group: Control (Control group, no clove oil) Second group: 0.5 Co $(0.5 \%$ v/w Clove oil added) Third group: 1 Co (1\% v/w Clove oil added)

Clove oil was added onto the surface (two sides) of each fillet using a micropipette followed by mild uniform distribution (directly with gloved fingers) of the oil for each sample. The clove oil ratio was determined by preliminary studies. All samples were vacuum-packaged and stored in $-18{ }^{\circ} \mathrm{C}$ and analysed once a month during 6 month to determine the microbiological and sensory attributes.

\section{Microbiological analysis}

Rainbow trout $(10 \mathrm{~g})$ obtained from each fillet were transferred aseptically to a Stomacher bag containing $90 \mathrm{ml}$ of sterile $0.1 \%$ peptone water (Buffer Peptone Water, LAB M) and homogenised for 1 min using a laboratory blender (Stomacher 400, Lab. Blender, London, UK) at high speed. Tenfold successive dilutions were made with $0.1 \%$ peptone water from these homogenates as required. Petri dishes for determination of the total anaerobe on brewer anaerobe agar and then incubated at $30{ }^{\circ} \mathrm{C}$ for 3 days. Psychrophile was determined on Plate Count Agar (PCA, Merck 1.05463) after incubation at $7^{\circ} \mathrm{C}$ for 10 days. Lactic acid bacteria were enumerated on de Man Rogosa Sharpe agar (MRS, Oxoid, CM361) incubated at $30^{\circ} \mathrm{C}$ for 5 days. Yeast and mold bacteria were enumerated on Potato Dextrose Agar (PDA, Merck 1.10130) incubated at 22 ${ }^{\circ} \mathrm{C}$ for 5 days enumerated. Microbiological counts were expressed as log colony-forming units (cfu) per gram of sample (Harrigan 1998; ICMSF, 1986).

\section{Sensory analysis}

Ten experienced panelists, staff members of the department of fish processing and technology, who had experience on fish and fish products were chosen to evaluate the quality of fillets. Panelists were asked to evaluate appearance, odor and texture of raw samples. Appearance, odor and texture were scored on a 10-point hedonic scale. A score of zero was used as a rejection attribute point (Simeonidou et al., 1997).

\section{Statistical analysis}

The study has been composed of three independent repetitions. By using the SAS program, the data was processed. According to General Linear Model (GLM) procedures, averages of the least squares were designated through Fisher's Least Significant Difference (LSD) test and the statistical significance level was taken as 0.05 hereby (SAS 1999).

\section{RESULTS AND DISCUSSION}

\section{Microbiological changes during frozen storage}

Deterioration of fish mainly occurs as a result of bacteriological activity leading to loss of quality and subsequent spoilage. Changes in the microbial flora (total anaerobe, psychrophilic bacteria, lactic acid bacteria, mold-yeast) of rainbow trout fillets during frozen storage are illustrated in Fig.1

Initial (1 $1^{\text {th }}$ month) total anaerobe counts was $0.95 \mathrm{log}$ cfu/g in all groups (Fig. 1). After storage of two months, significant differences $(p<0.05)$ were found between control group and clove oil treated groups. Bacteria populations increased in all groups during storage. However, the lowest bacteria counts were obtained from Group 1Co. At the end of the storage period of 6 months $4.55,3.14$ and $2.06 \log 10 \mathrm{cfu} / \mathrm{g}$ were measured for Control, 0.5 Co and 1 Co group, respectively. These results show that the addition of clove oil had effect on the total anaerobe bacteria of frozen trout. Similar studies show the effectiveness of essential oils such as clove applied to mean samples to prolong their shelf life, inhibiting microorganism growth and measuring the antioxidant activity and therefore increasing the product's shelf life (Burt, 2004)

The psychrophilic bacteria counts of control and other groups were recorded during frozen storage. Initial populations of psychrotrophic bacteria of Control, $0.5 \mathrm{Co}$ and $1 \mathrm{Co}$ samples were 2.14, 1.88 and $1.16 \log 10 \mathrm{cfu} / \mathrm{g}$, respectively. Psychrophilic bacteria counts of Control, $0.5 \mathrm{Co}$ and $1 \mathrm{Co}$ groups were $8.11,7.12$ and $7.20 \log 10 \mathrm{cfu} / \mathrm{g}$ at the end of the storage period, respectively. Based on the statistical analysis, clove oil treated groups had significantly lower $(p<0.05)$ counts when compared to control samples during storage. Control and $0.5 \mathrm{Co}, 1 \mathrm{Co}$ samples exceeded the value of $6 \mathrm{log} \mathrm{cfu} / \mathrm{g}$ for psychrotrophic bacteria count, considered as the upper acceptability limit for fish and fish products, after 4 months and 6 of storage, respectively. Therefore, compared with the control samples, a shelf life extension of 2 months was achieved for clove oil treated samples, as determined by psychrotrophic bacteria counts. Our results for psychrophilic bacteria are in agreement with findings of fresh fish species stored with other essential oils (Erkan, 2007; Ozyilmaz 2007; Attouchi and Sadok; 2011; Emir Çoban and Patır 2013). 

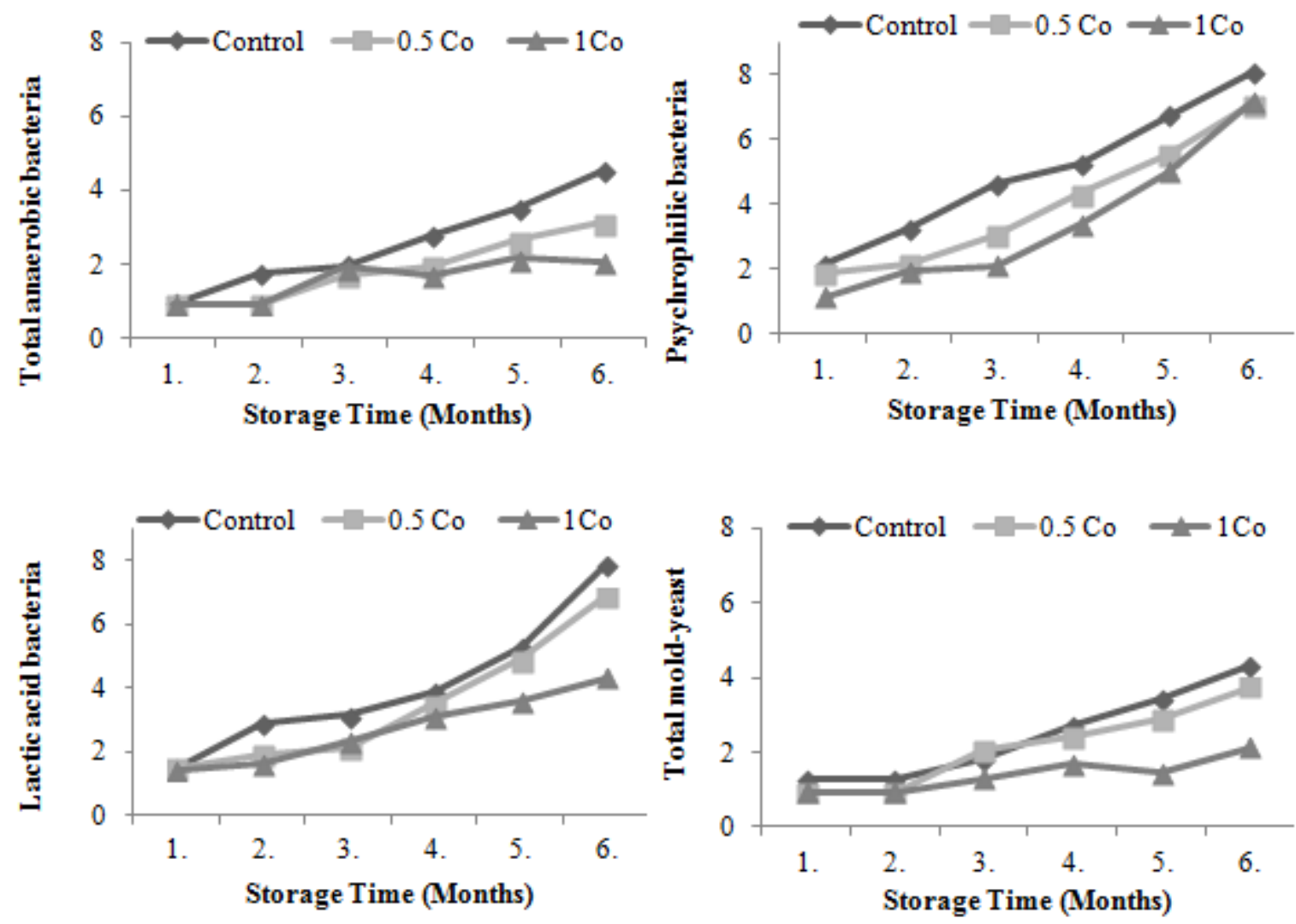

Figure 1. Changes in the microbial flora of rainbow trout fillets during frozen storage. Control: without clove oil vacuum packaged $0.5 \mathrm{Co}$ : added clove oil $0.5 \% \mathrm{v} / \mathrm{wt}$, vacuum packaged 1 Co: added clove oil $1 \% \mathrm{v} / \mathrm{wt}$, vacuum packaged

Vacuum-packed food is stored in the absence of oxygen and some microorganisms have restricted growth. Instead, the bacterial population occurs mainly of lactic acid bacteria. In vacuum-packed seafood, lactic acid bacteria are problematic as they produce typically sour odors and flavours. Lactic acid bacteria counts of Control, $0.5 \mathrm{Co}$ and $1 \mathrm{Co}$ groups (LAB) were determined as $1.50,1.51$ and $1.40 \log 10 \mathrm{cfu} / \mathrm{g}$, respectively at the beginning of storage. LAB counts in all groups increased during storage (Fig 1). Increases in treated groups were less than the control group. These results may explain the inhibitory effects of essential oils on LAB (Burt, 2004; Emir Çoban and Patır 2013). Kostaki et al (2009), reported that the treatment of fresh fish fillets (sea bass) with a mixture of thyme oil reduced the final LAB counts by approximately 1 log, compared with control group. Likewise, Kykkidou et al. (2009) reported that thyme-oregano oil treatment was effective in eliminatingthe growth of TVC and LAB in modified atmosphere packaged fish under refrigerated storage. They are also in agreement with those reported by other researcher (Erkan 2007; Chouliara et al.2007; Kykkidou et al. 2009; Atrea et al. 2009; Emir Çoban and Patır 2013).
In the present study, the number of yeast-mold of control and clove oil treated samples were determined as 1.26 and $0.95 \log 10 \mathrm{cfu} / \mathrm{g}$, respectively at the beginning of storage. Yeast-mold amount increased in all groups during storage (Fig 1). Yeast-mold populations were highest in the control samples, as expected, compared to the added clove oil samples. Clove oil causes a decrease in the number of bacterial cells, demonstrating they can be used to protect a food matrix such as fish, prolonging the bacteria lag period and that's why prolonging its shelf life. Similar findings have been found by Suhr and Nielsen (2003) and Emir Çoban and Patır (2013).

\section{Sensorial changes during frozen storage}

The acceptability of fish products during frozen storage depends on the changes in their sensory attributes. Fish products were considered to be acceptable for human consumption until the sensory score reached 4 (Amerine et al.1965; El-Hanafy et al. 2011). The sensory scores of frozen trout fillet with clove oil are presented in Fig 2. 


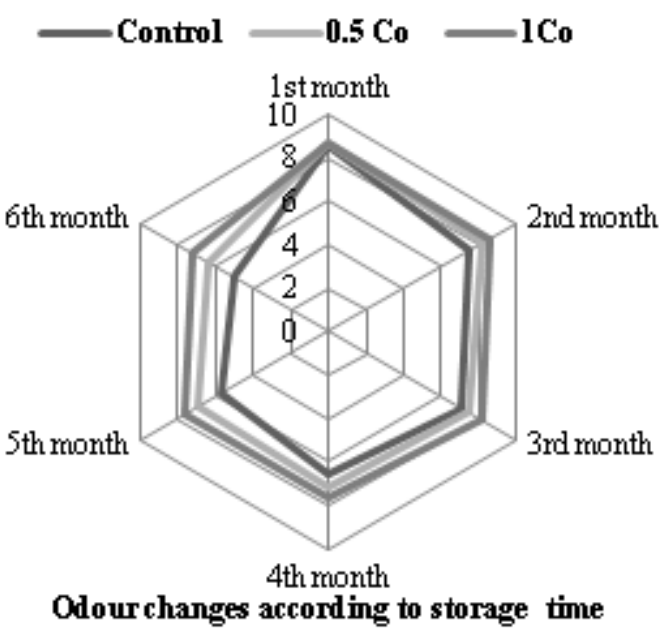

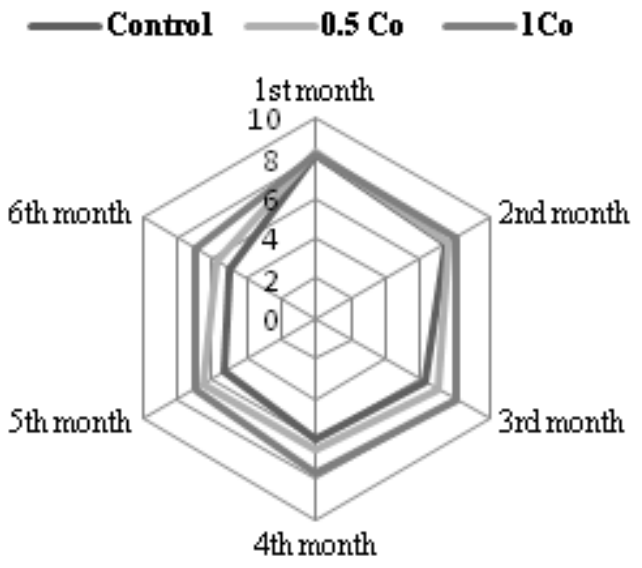

Colorchanges according to storage time

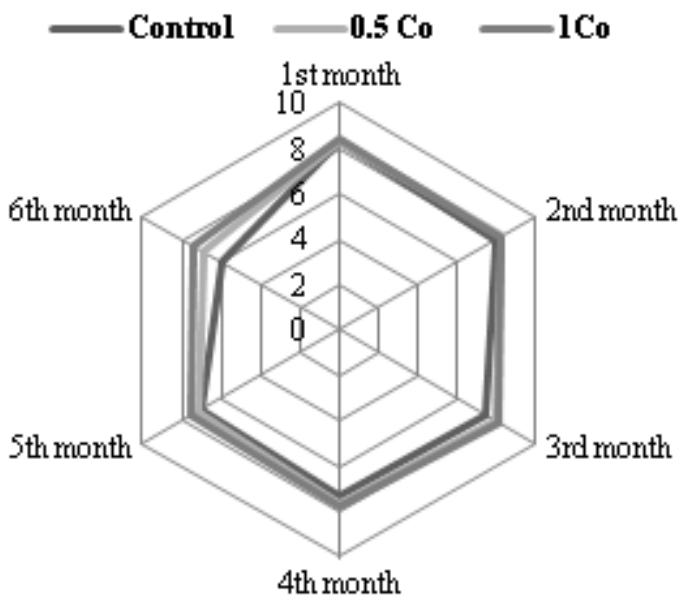

Texture changes according to storage time

Figure 2. The results of the sensory evaluation of rainbow trout fillets during frozen storage Control: without clove oil vacuum packaged $\mathbf{0 . 5}$ Co: added clove oil $0.5 \% \mathrm{v} / \mathrm{wt}$, vacuum packaged $1 \mathrm{Co}$ : added clove oil $1 \% \mathrm{v} / \mathrm{wt}$, vacuum packaged.

All the samples at $1^{\text {th }}$ months had high odour scores ranged from 8.5 to 8.7 , which means that all samples at initially were in excellent quality. During the storage period, there was a significant loss in the fish quality for all samples. Odour score of control, $0.5 \mathrm{Co}$ and $1 \mathrm{Co}$ groups were determined as 5, 6.4, 7.2 , respectively at $6^{\text {th }}$ months. Similar findings were reported by other researcher (Özyilmaz 2007; Chouliara et al. 2007; Emir Çoban and Patır 2013). Plant extract applied groups were more preferred than control groups like in our study.

Initially the best odour score were found in control samples, however the score significantly decreased at the end of the storage period. The samples treated with $0.5 \%$ clove oil were the most preferred fillets followed by the samples with $1 \%$ clove oil. (Fig 2).

Chemical and physical changes of proteins occurring during frozen storage may result in texture deterioration. This is an important problem because it negatively affects sensory quality. Texture modification is mainly a result of damage caused to the protein structure. In Fish, most of these changes are caused by the production of formaldehyde in the muscle (Sotelo et al. 1995). The formaldehyde liberated reacts with proteins to form crosslinks. These changes also causes loss of taste and odor. The rainbow trout fillets treated with clove oil were the most preferred samples in terms of sensory characteristics, whereas control samples had low sensory scores.

\section{CONCLUSION}

Consumer demands for foods with a prolonged shelf life are of major importance. Ensuring food safety and at the same time meeting demands for retention of nutrition and quality attributes has resulted in increased interest in alternative preservation techniques for inactivating microorganisms. 
This study has clearly shown that preservation of frozen fish applying clove oil have longer shelf life than normal. Moreover, as fish has good sensory quality, a proper preservation technique suggested in this paper is highly relevant.

\section{REFERENCES}

Amerine, M.A., Pongborn, R.H. \& Roescler, E.B. (1965). Principles of Sensory Evaluation of Food, p. 602, Academic Press, NewYork, NY.

Atrea, I., Papavergou, A., Amvrosiadis, I. \& Savvaidis, I.N. (2009). Combined effect of vacuum-packaging and oregano essential oil on the shelf-life of Mediterranean Octopus (Octopus vulgaris) from the Aegean Sea stored at $4^{\circ}$ C. Food Microbiol. 26: 166-172. doi: 10.1016/j.fm.2008.10.005

Attouchi, M. \& Sadok, S. (2011). The effects of essential oils addition on the quality of wild and farmed sea bream (Sparus aurata) stored in ice. Food Bioprocess Technol. 5: 1803-1816. doi: 10.1007/s11947-011-0522-x

Burt, S. (2004). Essential oils: Their antibacterial properties and potentia applications in foods - a review. Int. J. Food Microbiol. 94: 223-253. doi: 10.1016/j.ijfoodmicro.2004.03.022

Chouliara, E., Karatapanis, A., Savvaidis, I. N. \& Kontominas, M. G. (2007) Combined effect of oregano essential oil and modified atmosphere packaging on shelf-life extension of fresh chicken breast meat, stored at 4 ${ }^{\circ}$ C. Food Microbiol. 24: 607-617. doi: 10.1016/j.fm.2006.12.005

Dusukcan, M., Eroglu, M., Canpolat, O., Çoban, M.Z., Çalta, M. \& Şen, D., 2014. Distribution of Some Heavy Metals in Muscle Tissues of Luciobarbus. Turkish Journal of Science \& Technology 9 (1): 37-46.

El-Hanafy, A.E.A., Ramadan, M.F., Ahmed, M.H. \& Showky, H.E. (2006) Changes in fatty acid composition, cholesterol contents and quality attributes of bolti (Tilapia nilotica) fingerlings in relation to dietary lipid levels and sources in feeding regime. Dtsch. Lebensmitt. Rundsch. 102 518-522.

Emir Çoban, Ö. \& Patır, B.(2013). Antimicrobial and antioxidant effects of clove oil on sliced smoked Oncorhynchus mykiss. J. Verb. Lebensm. 8: 195199. doi: 10.1007/s00003-013-0823-2

Erkan, N. (2007). Freshness and quality of aquacultured sea bass (Dicentrarchus labrax) and sea bream (Sparus aurata) stored in ice. Archiv für Lebensmittelhygiene. 58:3, 98-106.

Goulas, A. E. \& Kontominas, M. G. (2007). Combined effect of light salting modified atmosphere packaging and oregano essential oil on the shelf-life of sea bream (Sparus aurata): biochemical and sensory attributes. Food Chemistry, 100: 287-296. doi: 10.1016/j.foodchem.2005.09.045

Harpaz, S., Glatman, L., Drabkin, V. \& Gelman, A. (2003). Effects of herbal essential oils used to extend the shelf-life of freshwater-reared Asian sea bass fish (Lates calcarifer). J. Food Prot. 66: 410-417. doi: 10.4315/0362-028X-66.3.410

Harrigan, W.F. (1998). Laboratory Methods in Food Microbiology, $3^{\text {rd }}$ ed Academic Press., London

ICMSF (International Commisson on Microbiological Spescifications for Foods), 1986. Microorganisms in Foods 2. sampling for microbiological analysis, $2^{\text {nd }}$ edition, University of Toronto Press, Toronto

Kostaki, M., Giatrakou, V., Savvaidis, I. N. \& Kontominas, M. G. (2009) Combined effect of MAP and thyme essential oil on the microbiological, chemical and sensory attributes of organically aquacultured sea bass (Dicentrarchus labrax) fillets. Food Microbiol.26: 475-482.

\section{ACKNOWLEDGEMENTS}

This study was presented as poster presentation at the First International Fisheries Symposium in Northern Cyprus 24-27 th March, 2013.

doi: 10.1016/j.fm.2009.02.008

Kykkidou, S., Giatrakov, V., Papavergou, A., Kontominas, M. G., \& Savvaidis, I. N. (2009). Effect of thyme essential oil and packaging treatments on fresh Mediterranean swordfish fillets during storage at $4{ }^{\circ} \mathrm{C}$. Food Chem. 115: 169-175. doi: 10.1016/j.foodchem.2008.11.083

Mahmoud, B. S. M., Yamazaki, K., Miyashita, K., Kawai, Y., Shin, S. \& Suzuki, T. (2006). Preservative effect of combined treatment with electrolyzed $\mathrm{NaCl}$ solutions and essential oil compounds on carp fillets during convectional air-drying. Int. J.Food Microbiol.106 (3): 331-337. doi: 10.1016/j.ijfoodmicro.2005.09.010

Nzeako B.C., Al-Kharousi Z.S.N. \& Al-Mahrooqui Z. (2006). Antimicrobia activities of clove and thyme extracts. Sultan Qaboos Univ Med J. 6: 3339.

Ozyllmaz, A. (2007). The effect of thyme essential oil on the shelf-life of rainbow trout (Onchorhynhus mykiss,Walbaum, 1792) fillets. Mustafa Kemal University, Master Thesis, Hatay, Turkey.

Simeonidou S, Govaris A \& Vareltzis K. (1997). Effect of frozen storage on the quality of whole fish and fillets of horse mackerel (Trachurus trachurus) and mediterranean hake (Merluccius mediterraneus). Z Lebensm Unters Forch A, 204: 405-410. doi: 10.1007/s002170050102

Solanki J., Parmar P., Parmar H.P., Chavda V. \& Kotiya A. (2016). Effect of clove oil treatment on the frozen storage Indian mackerel (Rastrelliger kanagurta) steaks. International journal of processing and post harvest technology, 7 (2):269-273

Sotelo, C., Piñeiro, C. \& Pérez-Martín, R. (1995). Review. Denaturation of fish proteins during frozen storage: Role of formaldehyde. Z. Lebensm. Unters. Forsch. 200: 14-23. doi: 10.1007/BF01192902

SAS (Statistical Analyses System).(1999). 8. Version. Cary, SAS Institute Inc.

Suhr, K.I. \& Nielsen, P.V. (2003). Antifungal activity of essential oils evaluated by two different application techniques against rye bread spoilage fungi. J.Applied Microbiol. 94: 665-674. doi: 10.1046/j.1365-2672.2003.01896.x

Tironi, V., Tomás, M. \& Añón, M.C. (2010). Quality loss during the frozen storage of sea salmon (Pseudopercis semifasciata). Effect of rosemary (Rosmarinus officinalis) extract. Lewensm. Wiss. Technol. 43: 263- 272. doi: 10.1016/j.Iwt.2009.07.007

Tuna Keleştemur, G. \& Ozdemir, Y. (2013). Effects of dietary vitamin A and E on growth performance and antioxidant status in blood of juvenile Rainbow trout (Oncorhynchus mykiss, W. 1792) exposed to flow rate stress. J. Anim. Plant Sci . 23(3):821-827.

Tuna Keleştemur, G. (2011). The antioxidant vitamin (A, C, E) and the Lipid Peroxidation Levels in Some Tissues of Juvenile Rainbow trout (Oncorhynchus mykiss, W. 1792) at different oxygen levels. Iran J Fish Sc. 11(2): 315-324.

Yıldız Oguzhan, P. (2015). Combine effects of essential oils and packaging on smoked rainbow trout stored $4^{\circ} \mathrm{C}$. Packag. Technol.Sci., 28: 987-997. doi: $10.1002 /$ pts. 2177 